\title{
Environmental preservation amidst carbon emissions, energy consumption, and urbanization in selected african countries: Implication for sustainability
}

\author{
Solomon Prince Nathaniel ${ }^{a, *}$, Ngozi Adeleye ${ }^{b}$ \\ a Department of Economics, University of Lagos, Akoka, Nigeria \\ ${ }^{\mathrm{b}}$ Department of Economics, Covenant University, Ota, Ogun State, Nigeria
}

\section{A R T I C L E I N F O}

\section{Article history:}

Received 31 July 2019

Received in revised form

11 November 2020

Accepted 2 December 2020

Available online 9 December 2020

Handling editor. Kathleen Aviso

\section{JEL Classification:}

C52

040

055

Q43

Q50

Keywords:

Carbon emissions

Ecological footprint

Energy usage

Urbanization

Africa

\begin{abstract}
A B S T R A C T
On the quest for a clean and sustainable environment, the Sustainable Development Goal (SDG) 8 stipulates the need to reduce carbon emissions, decarbonize the energy system, improve energy consumption and ensure the attainment of sustainable energy. In the same vein, SDG 9 pertains to the prevention of environmental degradation, promoting biodiversity and preserving the ecosystem to support inclusive human and economic development. Given the hazardous impact of carbon emissions, if left unabated, and the benefits of preserving nature's ecosystem, the motivation for this study hinges on analyzing factors that threaten a sustainable environment using two proxies of environmental degradation: carbon emissions and ecological footprint. With a battery of static and dynamic econometric techniques on a sample of 44 selected African countries from 1992 to 2016, findings reveal the following: (1) energy usage deteriorates the environment, and (2) urbanization has asymmetric effects on the environment. Controlling for per capita GDP, financial development and gross fixed capital formation, evidence suggests that per capita GDP has an asymmetric impact, financial development accelerates environmental degradation, while gross fixed capital formation intensifies a sustainable environment. Policy outcomes and implications for sustainability are discussed.
\end{abstract}

() 2020 Elsevier Ltd. All rights reserved.

\section{Introduction}

Carbon emissions $\left(\mathrm{CO}_{2}\right)$ has gained unprecedented attention all over the world, especially among economists and environmentalists, due to its contribution to global warming and environmental degradation. $\mathrm{CO}_{2}$ emissions is a big threat to biodiversity and sustainable development (Nathaniel and Iheonu 2019). Unfortunately, the activities of humans remain the main driver of global emissions (Li et al., 2019). The unending debate from the turn of the 21st century has been on matters relating to the concomitant increase in $\mathrm{CO}_{2}$ emissions and global warming (Liu and Xiao 2018). This has necessitated global actions from different quarters. The global

\footnotetext{
* Corresponding author.

E-mail addresses: nathaniel solomon21@yahoo.com, nathanielsolomon21@ gmail.com (S.P. Nathaniel), ngozi.adeleye@covenantuniversity.edu.ng (N. Adeleye).
}

atmospheric $\mathrm{CO}_{2}$ emissions concentration averaged $404.7 \mathrm{pmm}$ in 2016 (ESRL, 2017). Hansen et al. (2017) provided evidence that global temperature is now in excess of $1.26{ }^{\circ} \mathrm{C}$. Be that as it may, countries in Africa generate fewer emissions (EIA, 2013) as the US and China lead the pack (Liu and Xiao, 2018). However, Africa countries are not spared from the calamitous effects of global warming (Table 1 ).

$\mathrm{CO}_{2}$ emissions affect human health negatively. The pollution that emanates from it contributes to all forms of mortality, through its influence on human health (Khan et al., 2019b). This is even more worrisome considering that Africa has the highest mortality rate in the world (WHO, 2015). To curb this menace, there are calls from studies in the literature for African countries to shift their attention to renewable energy sources (Nathaniel, 2019) because they are clean (Zhang et al., 2019), low in emissions, and enhance environmental sustainability (Nathaniel et al., 2019). On the flip 
Table 1

Summary of Literature on Economic Growth, Energy Consumption, and Environmental degradation.

\begin{tabular}{|c|c|c|c|c|}
\hline Author & Country(s)/Region & Duration & Method & Finding(s) \\
\hline Ansari et al. (2020) & 37 Asian countries & $1991-2017$ & GMM & $\mathrm{G}$ and $\mathrm{EU}$ increase EF. \\
\hline $\begin{array}{l}\text { Altıntaş and Kassouri } \\
\quad(2020)\end{array}$ & Europe & $1990-2014$ & CCEMG & $\begin{array}{l}\text { EU increases the EF. Europe could benefit more from consuming } \\
\text { renewables. }\end{array}$ \\
\hline Baz et al. (2020) & Pakistan & $1971-2014$ & NARDL & $\mathrm{EF} \rightarrow \mathrm{EU}$. No direction of causality was witnessed between $\mathrm{G}$ and $\mathrm{EF}$. \\
\hline $\begin{array}{l}\text { Ulucak and Khan } \\
\text { (2020) }\end{array}$ & BRICS & $1992-2016$ & DOLS, FMOLS. & $G$ and URB add to the EF. \\
\hline Dogan et al. (2020) & BRICST & $1980-2014$ & AMG & G, alongside energy structure and intensity are chief drivers of EF. \\
\hline Sharma et al. (2020) & Asia & 1990-2015 & PMG & $\mathrm{G}$, URB, and EU increase the EF. \\
\hline $\begin{array}{l}\text { Destek and Sinha } \\
\quad(2020)\end{array}$ & OECD & $1980-2014$ & DOLS, CCEMG. & EU increases the EF, while G declines the EF. \\
\hline Aziz et al. (2020) & Pakistan & $1990-2018$ & Quantile ARDL & $\begin{array}{l}\mathrm{G} \text { increases the EF. However, renewable energy consumption and forest } \\
\text { area decrease the EF. }\end{array}$ \\
\hline Sharif et al. (2020) & Turkey & $\begin{array}{l}\text { 1965Q1- } \\
\text { 2017Q4 }\end{array}$ & Quantile ARDL & $\mathrm{EU} \leftrightarrow \mathrm{EF} . \mathrm{G} \leftrightarrow \mathrm{EF}$. Renewable energy $\leftrightarrow \mathrm{EF}$ \\
\hline Khan et al. (2020) & China, India, and Pakistan & $1970-2016$ & FMOLS, DOLS. & $\mathrm{G}$ increases $\mathrm{EF}$ in all the countries. \\
\hline Ma et al. (2019) & China & $2005-2016$ & Kaya Identity, LMDI. & $\mathrm{G}$ drivers $\mathrm{CO}_{2}$ emissions. \\
\hline Ghazali and Ali (2019) & $\begin{array}{l}10 \text { newly industrialized } \\
\text { countries }\end{array}$ & $1991-2013$ & FMOLS, DOLS. & POP, $\mathrm{G}$ and $\mathrm{EU}$ drive $\mathrm{CO}_{2}$ emissions. POP $\leftrightarrow \mathrm{CO}_{2}$. $\mathrm{CO} 2 \leftrightarrow$ energy intensity. \\
\hline Churchill et al. (2019) & G7 countries & $1870-2014$ & $\begin{array}{l}\text { Non-parametric panel data } \\
\text { model. }\end{array}$ & The relationship between $\mathrm{CO}_{2}$ and $\mathrm{R} \& \mathrm{D}$ is time-varying. \\
\hline Sarkodie et al. (2019) & Australia & $1970-2017$ & Dynamic ARDL simulations. & $\begin{array}{l}\text { EU increases } \mathrm{CO}_{2} \text { emissions. Biomass consumption reduces emissions by } \\
13 \% \text {. }\end{array}$ \\
\hline $\begin{array}{l}\text { Nguyen and Kakinaka } \\
\text { (2019) }\end{array}$ & 107 countries & 1990-2013 & Panel cointegration & $\mathrm{RE}$ is negatively associated with $\mathrm{CO}_{2}$ emissions for high-income countries. \\
\hline Lin and Raza (2019). & Pakistan & $1978-2017$ & LMDI, Scenerio analysis. & Energy intensity reduces $\mathrm{CO}_{2}$ emissions. \\
\hline $\begin{array}{l}\text { Shabani and Shahnazi } \\
\text { (2019) }\end{array}$ & Iran & $2002-2013$ & DOLS, VECM & $\mathrm{GDP} \rightarrow \mathrm{CO}_{2}$, and $\mathrm{EU} \rightarrow \mathrm{CO}_{2}$ in all sectors. \\
\hline Chang et al. (2019) & 121 countries & $2000-2014$ & LMDI & $\mathrm{EU}, \mathrm{G}$, and $\mathrm{CO}_{2}$ intensity are the four drivers of emissions. \\
\hline Acheampong (2018) & 116 countries & 1990-2014 & GMM & $\mathrm{CO}_{2} \leftrightarrow \mathrm{G} . \mathrm{CO}_{2} \leftrightarrow \mathrm{EU}$ \\
\hline Liu and Hao (2018) & 69 countries & 1970-2013 & VECM, FMOLS, DOLS & $\mathrm{CO}_{2} \leftrightarrow \mathrm{EU} . \mathrm{EU} \leftrightarrow \mathrm{G}$ in the long-run. \\
\hline Sarkodie (2018) & 17 countries & $1971-2013$ & $\begin{array}{l}\text { Random and fixed effect } \\
\text { models }\end{array}$ & $\mathrm{G} \rightarrow \mathrm{CO}_{2} . \mathrm{EU} \rightarrow \mathrm{CO}_{2}$ \\
\hline Shahbaz et al. (2018) & Japan & $1970-2014$ & ARDL & EU and G drive emissions. \\
\hline $\begin{array}{l}\text { Salahuddin et al. } \\
\text { (2018) }\end{array}$ & Kuwait & 1980-2013 & ARDL, DOLS, VECM & EU and $\mathrm{G}$ stimulate $\mathrm{CO}_{2}$ emissions. $\mathrm{G} \rightarrow \mathrm{CO}_{2}, \mathrm{EU} \rightarrow \mathrm{CO}_{2}$. \\
\hline Mahalik et al. (2018) & BRICS & 1980-2013 & ARDL & $\begin{array}{l}\mathrm{EU} \text { (petroleum products) drives } \mathrm{CO}_{2} \text { emissions for all countries except } \\
\text { Brazil. }\end{array}$ \\
\hline Zhou et al. (2018) & China & $2003-2015$ & ARDL & G reduces emissions in China. \\
\hline
\end{tabular}

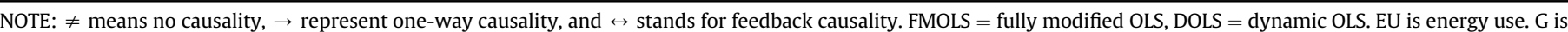

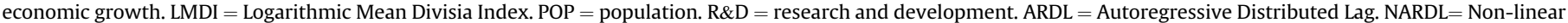

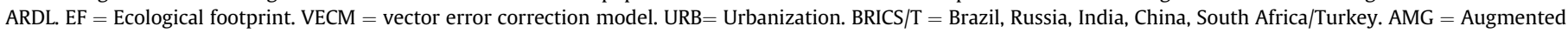
Mean Group. CCEMG = Common Corrected Mean Group.

Source: Authors' Compilations

side, though Africa is rich in clean energy sources (Aliyu et al., 2018), they still rely heavily on non-renewable sources that degrade the environment (da Silva et al., 2018). The present study considers Africa because the continent is vulnerable to the menace created by climate change and still consumes more of nonrenewable energy sources despite its renewable energy potentials.

The quest to make the world habitable for humanity has led to various studies seeking to unveil the drivers of $\mathrm{CO}_{2}$ emissions (Wang et al., 2019). The most recent studies suggest that economic growth is the key driver of emissions (Mardani et al., 2019). Several studies have analyzed the determinants of $\mathrm{CO}_{2}$ emissions using frameworks within time series analysis: for instance, the synergy among environmental pollution, economic growth, and energy use (Shahbaz and Sinha, 2019); and multivariate analysis of pollution, economic growth, and energy use (Asongu et al., 2016) to mention a few. These studies have yielded conflicting results. This discrepancies in findings, as it relates to previous studies, could be traced to the various proxies used to capture environmental degradation, the peculiarity of the region/country/countries considered, the methodology used to analyze the data, as well as, the consideration given to variables that go into the model.

The Sustainable Development Goals (SDGs) highlights the need for countries to reduce emissions, improve energy consumption, decarbonize the energy system, and ensure the attainment of energy that is sustainable. The SDGs further crave for the mitigation of environmental degradation, and the need to protect the biodiversity, and preserve the ecosystem to support inclusive human and economic development. As of 2014, SSA had a population of about 979 million people. This figure has however been projected to hit 1 billion before 2020 (da Silva et al., 2018). This upward surge in population has implications for urbanization and energy consumption. Urbanization in Africa is observed relatively fast. It has been rapid in SSA (United Nation, 2018). Urbanization rate in Africa increased from $30.8 \%$ to $38.8 \%$ between 2000 and 2017, while the rate of economic growth also averaged 2.2\% between 2015 and 2017 (Wang and Dong, 2019). Energy consumption rises with population increase amidst economic growth (Dogan et al., 2019). Unfortunately, energy consumption in Africa is largely non-renewable. Non-renewable energy is not environmentally friendly as they add to emissions and degrade the environment, thereby inhibiting environmental sustainability. Therefore, this prompted the need to consider the role of urbanization, population, economic growth, and energy consumption on environmental degradation in Africa and its implications for sustainability. Studies that have examined the energy-growth-environmental nexus for developing countries, Africa inclusive, have focused more on the impact of growth and energy consumption on ambient air pollution measured by $\mathrm{CO}_{2}$ emissions while totally ignoring sustainable development which 
has been re-emphasized by means of the SDGs. This study is designed to address this issue.

The outlined objectives of this study are as follows: to show the impact of each explanatory variable as other covariates are included in the model, to assess if the statistical and economic significance of each variable changes as other covariates are incorporated, and to determine which variable has a dominant influence on environmental degradation.

This study adds to the already existing literature in the following ways: (i) unlike previous studies that used only $\mathrm{CO}_{2}$ emissions (a negative indicator), to capture environmental degradation, this study adopted $\mathrm{CO}_{2}$ emissions and ecological footprint (EF) (a positive indicator), to measure environmental quality in Africa. The reason for this choice is borne out of the fact that EF is a comprehensive indicator that captures environmental degradation better than $\mathrm{CO}_{2}$ emissions (Destek and Sinha 2020). Unlike $\mathrm{CO}_{2}$ emissions, $\mathrm{EF}$ accounts for other natural areas, such as availability of water resources, arable farmland and freshwater, forest reserves, and fresh air that is essential for economic growth. The World Wildlife Fund and the United Nations Environment Programme use EF for their policy reports (Rudolph and Figge 2017). (ii) Also, a comparative analysis of the effects of each of the variables on both indicators of environmental degradation was carried out with robust econometric techniques. (iii) The very few studies that focused on Africa/sub-Sahara African (SSA), used methodologies that either ignored cross-sectional dependence or endogeneity among the countries, knowing fully well that this can render the t-statistic invalid thereby yielding misleading results (Khan and Qianli 2017b; Nathaniel and Iheonu, 2019). As such, we make up for these inefficiencies by bolstering the study with static models that correct for cross-sectional dependence, endogeneity, autocorrelation and heteroscedasticity across and within panels.

The remainder of the study is designed as follows: Section 2 displays the literature review. Section 3 presents the data and the empirical approach. Section 4 shows the findings and discussion. Section 5 concludes with relevant policy directions. Section 6 discusses the implications of the findings for sustainability in Africa.

\section{Literature review}

The role of different variables on the environment has gained lots of attention among economists and environmentalists. More so, various methodologies and techniques have been explored to examine this relationship both for specific-country and crosscountry studies. The most recent of these studies have argued that the greatest impact on $\mathrm{CO}_{2}$ emissions is exacted by economic growth (Ma et al., 2019; Khan et al., 2020).

\subsection{The impact of energy consumption and economic growth on $\mathrm{CO}_{2}$ emissions}

For more than four decades now, many studies have been channelled towards the interaction between economic growth, energy consumption, and environmental degradation, with models built within the EKC framework (Destek and Sinha 2020). Several indicators of environmental degradation have been used, such as sulfur dioxide (Jayanthakumaran and Liu 2012), $\mathrm{CO}_{2}$ emissions (Sarkodie and Ozturk 2020; Abokyi et al., 2019; Khan et al. 2018, 2019b), and EF (Destek and Sinha 2020; Aydin et al., 2019). The first two are negative indicators while EF is a positive indicator. Sarkodie and Strezov (2019) explored the energy- $\mathrm{CO}_{2}$ emissions nexus in five developing countries including South Africa from 1982 to 2016. They discovered that energy consumption increases $\mathrm{CO}_{2}$ emissions, but for the case of Indonesia, FDI was the main culprit. Khan et al. (2018) applied the GMM technique to investigate the influence of energy demand and logistics operations on environmental sustainability in 43 countries. It was discovered that logistics operations demands energy (fossil fuels), and energy, harm the environment.

\subsection{The impact of energy consumption and economic growth on $E F$}

Recent studies have focused on EF as an indicated of environmental degradation because of the criticism levelled against $\mathrm{CO}_{2}$ emissions. He et al. (2019) examined the impact of energy use and economic growth on EF for Malaysia from 1978 to 2013. Their findings suggest that the aforementioned variables contribute to environmental degradation. Fakher (2019) explored the determinant of EF in OPEC countries. They discovered that energy consumption, population, and economic growth are the drivers of environmental deterioration in OPEC. Destek and Sinha (2020) examined the link between renewable energy, trade, economic growth and EF in 24 OECD countries. The study applied the FMOLS, CCEMG, and DOLS for its analysis. They discovered that renewable energy abates environmental degradation, while non-renewable energy adds to it. These findings are in consonance with that of Danish and Wang (2019) for the N11 countries. Zafar et al. (2019) controlled for natural resources and FDI while investigating the effect of human capital, energy consumption and economic growth on EF in the United States. From the ARDL results, human capital reduces $\mathrm{EF}$, while energy consumption contributes to environmental deterioration. Ahmed and Wang (2019) also reported a similar result, in terms of the findings of Zafar et al. (2019), for India. The findings of both authors affirmed the environmental friendly role of human capital and therefore called for the development of human capital. Sabir and Gorus (2019) discovered a positive relationship between FDI, globalization, economic growth, and EF in South Asian countries. Mikayilov et al. (2019) examined the EKC for EF in Azerbaijan from 1996 to 2014. Apart from urbanization, trade and energy consumption were the other factors that degrade the environment. Studies like Khan et al. (2016), Halicioglu and Ketenci (2016), and Dinda (2004) had earlier examined the EKC without considering EF.

\section{Data and model}

The study uses panel data on 44 selected African countries from 1992 to 2016. The selection of countries is subject to data availability. The data on EF ends in 2016. All variables are in per capita formations. For the analyses, the study deploys a sequence of static estimators such as panel-corrected standard errors (PCSE), and spatial correlation consistent (PSCC) standard errors for linear panel models; and dynamic estimators such as Arellano-Bond dynamic panel data (DPD) and Arellano-Bond/Blundell-Bover system GMM. These techniques are explained in Section 3.2.

\subsection{Variables and expectations}

To achieve the study objectives and in line with similar works, a total of eight (8) variables are used: $\mathrm{CO}_{2}$ emissions per capita $(C R B N)$, ecological footprint per capita $(E F)$, energy use per capita (ENGY), urban population (URB), urban population growth (URBGR), GDP per capita $(P C)$, financial development $(F I N)$, and gross fixed capital formation (GFCF). $\mathrm{CO}_{2}$ emissions and $\mathrm{EF}$ which proxy for environmental degradation have been extensively discussed in the introduction, hence, we focus on the relevance of other variables in the model. Energy usage measures the consumption rate at which the population uses energy. Most studies in the literature have attributed environmental degradation in emerging economies to energy consumption. In general, every economy consumes energy. 
However, the type of energy consumed matters. In Africa, for instance, fossil fuels, coal, and natural gas are the major energy sources. These energy sources are used for electricity generation and other domestic energy needs. They are non-renewable and therefore contributes to environmental deterioration. Therefore, we expect a positive relationship exists between energy use, EF, and $\mathrm{CO}_{2}$ emissions because more energy consumption elicits more emissions and in the aftermath, a degradation of the environment.

Likewise, urban population and urban population growth capture people living in the urban areas and the rate of migration from the rural to the urban areas. It is important to state that urban population growth is used for the carbon emissions equation while the urban population for the EF equation. Urbanization increases the population of cities which already possess limited resources. Consequently, the demand for water, housing, transportation, energy, food, commercial buildings, electric appliances, and public utilities etc. increases which accelerate pollution and drive climate change (Wang et al., 2019). Though urbanization promotes innovation, contributes to knowledge and economic development, it could also spread emissions and adversely impact local food production (Winoto and Schultink, 1996). In recent decades, Africa has been urbanizing rapidly. The speed of urbanization in SSA between 1950 and 2015, for example, was higher than for the more developed regions (United Nation, 2018). The urban population generate about seventy per cent of the total greenhouse gas (GHGs) emissions (UN-Habitat, 2016). Hence, the reason why urbanization was considered in this study.

Similarly, GDP per capita (our proxy for economic growth) measures the average income of the population in a given year. Economic growth can contribute to $\mathrm{CO}_{2}$ emissions since growth is accompanied by increasing energy consumption (mostly nonrenewable) and the consumption of natural resources which could trigger environmental pressure. Africa has witnessed a seemingly fair growth over the years, and the region's emissions level has continued to rise. We expect a positive relationship between economic growth and $\mathrm{CO}_{2}$ emissions as the region's economy appears to be energy and resource-dependent.

Financial development captures the depth of financial intermediation. It measures the ability of financial institutions to provide the needed finance to businesses and corporations that will aid the capacity to meet aggregate demand and expand production such that the expansion of production leads to more emissions and environmental degradation. Financial development could contribute to environmental degradation especially when financial resources are channelled to high-polluting sectors of the economy. Lastly, gross fixed capital formation measures the stock of investment in the economy. An increase in investment and industrial production is expected to facilitate an increase in $\mathrm{CO}_{2}$ emissions and endanger a clean environment since Africa has a weak environmental regulation and is mostly considered a pollution haven. Overall, the expected a priori is that these indicators exhibit positive relationships (and coefficients) with carbon emissions and EF.

\subsection{The model}

To achieve the research objectives of investigating the determinants of $\mathrm{CO}_{2}$ emissions and $\mathrm{EF}$, the study specifies two distinct models and engages the systematic estimation of four equations using static and dynamic techniques in accordance with similar panel data studies (Shahbaz et al., 2019; Sinha et al., 2019). To control for outliers and establish elasticity relationships, all variables with the exception of urban population growth are transformed into natural logarithms. With $C R B N$ and $E F$ as dependent variables, ENGY and URBGR (URB) as main explanatory variables and $P C, F I N$ and GFCF as control variables, the generalized model is specified in explicit form as:

$\ln Y_{i t}=\alpha+\beta \ln X_{i t}^{\prime}+\xi Z_{i t}^{\prime}+\left(\gamma_{i}+u_{i t}\right)$

where $\left(\gamma_{i}+u_{i t}\right)=\varepsilon_{i t}$ the composite error term; $\ln Y_{i t}$ is the natural logarithm of dependent variables $\left(\mathrm{CO}_{2}\right.$ and $\left.\mathrm{EF}\right) ; \boldsymbol{X}_{\boldsymbol{i t}}^{\prime}$ is the vector of explanatory variables (energy use per capita, and urban population/ growth); $\boldsymbol{Z}_{i t}^{\prime}$ is the vector of control variables (financial development, per capita GDP and gross fixed capital formation); $i$ is the number of countries in the sample $1,2, \ldots, 44 ; t$ is the number of years $1,2, \ldots, 25 ; \gamma_{i}$ indicates country-specific heterogeneity (country fixed effects); and $u_{i t}$ is the idiosyncratic error term that is independently and identically distributed (i.i.d).

To ensure results validity, this study applies static and dynamic techniques that eliminate the fixed effects in addition to controlling for other issues affecting panel data analysis such as cross-sectional dependence, autocorrelation, and heteroscedasticity. One of the static techniques is panel-corrected standard errors (PCSE) estimator which is an alternative to feasible generalized least squares (FGLS). It fits a linear cross-sectional time-series model on the assumption that the errors are by default heteroscedastic and contemporaneously correlated across panels. The second static estimator which accounts for cross-sectional dependence is the Driscoll and Kraay (1998) robust standard error technique. It uses the OLS/Weighted Least Squares and fixed effects (within) regression and computes spatial correlation consistent (PSCC) standard errors for linear panel models. The argument for dynamic estimations hinges on the fact that either the mean-differencing or firstdifferencing of equation [1] which eliminates $\gamma_{i}$ results in endogeneity of the regressors. That is:

$$
\begin{aligned}
& \ln \left(Y_{i t}-\bar{Y}\right)=(\alpha-\alpha)+\beta \ln \left(X_{i t}^{\prime}-\bar{X}\right)+\xi \ln \left(Z_{i t}^{\prime}-\bar{Z}\right)+\left(\gamma_{i_{i}}-\gamma_{i_{i}}\right) \\
& \quad+\left(u_{i t}-\bar{u}\right)
\end{aligned}
$$

Mean-differencing eliminates $\gamma_{i}$ from equation [2] and this reduces to:

$\ln \left(Y_{i t}-\bar{Y}\right)=\beta \ln \left(X_{i t}^{\prime}-\bar{X}\right)+\xi \ln \left(Z_{i t}^{\prime}-\bar{Z}\right)+\left(u_{i t}-\bar{u}\right)$

Likewise,

$$
\begin{aligned}
& \quad \ln \left(Y_{i t}-Y_{i t-1}\right)=(\alpha-\alpha)+\beta \ln \left(X_{i t}^{\prime}-X_{i t-1}\right)+\xi \ln \left(Z_{i t}^{\prime}-Z_{i t-1}^{\prime}\right) \\
& +\left(\gamma_{i}-\gamma_{i}\right)+\left(u_{i t}-u_{i t-1}\right)
\end{aligned}
$$

First-differencing eliminates $\gamma_{i}$ from equation [3] and this reduces to:

$\ln \left(Y_{i t}-Y_{i t-1}\right)=\beta \ln \left(X_{i t}^{\prime}-X_{i t-1}\right)+\xi \ln \left(Z_{i t}^{\prime}-Z_{i t-1}^{\prime}\right)+\left(u_{i t}-\left(u_{i t-1}\right)\right.$

The application of OLS to [2'] or [3'] provides biased and inconsistent estimates for the covariates of interest due to endogeneity (the transformed regressors are now correlated with the transformed error). This problem can be resolved by engaging an instrumental variables estimation technique. As a result, the study adopts two dynamic techniques: the Arellano and Bond (1991) dynamic panel data (DPD) estimator and Arellano and Bover (1995) generalized method of moments (system GMM). These estimators use instruments (moment conditions) that are uncorrelated with the regressors in the underlying algorithm during estimation. The validity of instruments used determines the consistency of the parameters that emanate from such an estimator. Two different specification tests put forward by Arellano and Bover 
(1995) and Arellano and Bond (1991) are used to examine the validity of the instruments: the Sargan statistic for DPD technique and Hansen statistic for GMM technique. Also included is the serial correlation of the error term.

\section{Results and discussions}

This sections chronologically detail the various simulations carried out beginning with pre-estimations (correlation analysis and summary statistics), presentation and discussion of results (Table 2).

\subsection{Correlation analysis and summary statistics}

Before engaging any regression analysis, it is essential to explore the inherent characteristics of the variables and the associations among them. Table 3 displays both the correlation relationships (upper part) with their measures of central tendency and dispersion (lower part). Given the functional forms of the models, the pairwise correlation analysis is performed using the logarithmic transformation of the variables while the summary statistics is done using the raw variables as transformations will erase all properties and significant features of each variable. In relation to the outcome variables, from the upper part, statistics reveal that energy use, urban population growth, per capita GDP and financial development exhibit strong and statistically significant associations with carbon emissions and EF. Among the covariates, several statistically significant associations are evident and close scrutiny indicates that none exhibit perfect linear relationships, hence, multicollinearity is not an issue which is supported by the results of the variance inflation factor (VIF) shown in Table 4.

Though, multicollinearity does not violate any regression assumptions, the OLS estimators are still BLUE (Best Linear Unbiased Estimators) as it does not destroy the property of minimum variance, but it affects the regression beta weights, standard errors and the corresponding statistical significance levels associated with them. Therefore, it has the potential of adversely affecting regression coefficients. The VIF tells the degree to which the standard errors are inflated due to the presence of multicollinearity and it is the reciprocal of the tolerance level $\left(\frac{1}{1-R^{2}}\right)$. So, if the tolerance level is 0.10 , the VIF $=10$. Tolerance level of 0.10 is accommodated, and anything below that signals the presence of multicollinearity. Consequently, tolerance levels above 0.10 are preferred. The results of the VIF in Table 4 shows that both models are purged of the problem of multicollinearity as the VIF for each regressor lie within the threshold of 0 (no multicollinearity) and 10 (high multicollinearity).

The lower part of Table 3 shows the average $\mathrm{CO}_{2}$ emissions of 1.92 metric tons (Mt) per capita. From the sample of countries, Ethiopia has the lowest average emissions of 0.04 (Mt) per capita in
1994 while South Africa has the highest at 9.979 (Mt) per capita in 2008. The standard deviation of 2.77 shows deviations from the sample average. For EF, the mean value is 4.39 per capita. Data shows that Nigeria has the highest value of 207, 299, 669.6 ghpc in 2014 while the country with the lowest value is Gabon with $1,245,635.243$ ghpc in 1997. For energy consumption, the country with the lowest energy use is Madagascar $(129.12 \mathrm{~kg}$ ) for the period 1994 while Gabon (3129.08) shows to have the highest for the period 2010. Also, wide variations in energy used $(622.45 \mathrm{~kg})$ and per capita GDP (1863.34 US\$) occur across the countries in the sample.

\subsection{Static and dynamic analysis: carbon emissions model}

The results for the $\mathrm{CO}_{2}$ emissions model from static and dynamic simulations are shown in Table 5 . Without recognizing country fixed effects (that is, heterogeneities) but controlling for robust standard errors, the PCSE analysis shows that energy usage, financial development, and per capita GDP exhibit statistically significant relationships at $1 \%$ level. The outcome suggests carbon emissions will respond to a percentage change in these indicators by 0.53 per cent increase, 0.12 per cent increase, and 0.45 per cent increase, respectively, on average, ceteris paribus. In essence, energy usage, financial development, and per capita income contribute to environmental degradation while urban population growth declines carbon emissions. The signs of the coefficients of energy usage and per capita income is in accordance with a priori expectations and the outcomes may not be unconnected with the assumption that as average income rises, people witness a positive lifestyle shocks with the propensity to use more energy via the consumption of physical and industrial goods such as fitting homes and offices with appliances, gadgets, purchase of new vehicles, and so on which inevitably contribute to polluting the environment. On the other hand, the coefficient of urban population growth contradicts expectations because it implies that carbon emissions decrease by 0.01 per cent. This finding is intuitive as it submits that as the population grows, there is the inclination to move towards using renewables, and hence, environmental pollution declines. These are important contributions to the literature.

Controlling for panel-correlated standard errors, cross-sectional dependence, and country fixed effects result from the PSCC estimations reveal that urban population growth, per capita GDP, energy usage, and financial development exhibit statistically significant relationships with carbon emissions. The coefficients of the four variables are similar to those of the PSCE in sign and magnitude. Hence, a similar interpretation holds. Given that financial development shows a statistically significant positive relation, it supposes that a percentage change in financial deepening contributes to environmental pollution by 0.09 per cent, on average, ceteris paribus. The rationale is justifiable because more financial deepening creates economic opportunities for firms to

Table 2

Data, measurement, and source.

\begin{tabular}{lll}
\hline S/N & Indicator Name & Measurement \\
\hline 1 & Energy use & kg of oil equivalent per capita \\
2 & Urbanization & percentage of total population \\
3 & Financial Development & \% of GDP \\
4 & real GDPPC (in billions USD) & in constant 2010 USD \\
5 & CO $_{2}$ emissions & metric tons per capita \\
6 & GFCF (in billions USD) & \% of GDP \\
7 & Urban population growth & annual \% \\
8 & Ecological Footprint & global hectares per capita \\
\hline
\end{tabular}

Note: GFN represents Global Footprint Network, Financial development is proxy by bank credit to the private sector. GFCF: gross fixed capital formation. Sources: Author's compilation. 
Table 3

Correlation analysis and descriptive statistics.

\begin{tabular}{|c|c|c|c|c|c|c|c|c|}
\hline Variables & CRBN & $\mathrm{EF}$ & ENGY & URBP & URBGR & PC & FIN & GFCF \\
\hline Carbon Emissions & 1.000 & & & & & & & \\
\hline Ecological Footprint & 0.457 & 1.000 & & & & & & \\
\hline Energy Use & 0.451 & 0.197 & 1.000 & & & & & \\
\hline Urban Population & 0.076 & 0.392 & 0.543 & 1.000 & & & & \\
\hline Urban Pop. Growth & 0.397 & 0.587 & 0.049 & 0.318 & 1.000 & & & \\
\hline GDP per capita & 0.723 & -0.119 & 0.547 & 0.189 & 0.329 & 1.000 & & \\
\hline Financial Development & 0.667 & 0.623 & 0.587 & -0.045 & -0.621 & 0.281 & 1.000 & \\
\hline Gross Fixed Cap. Form. & 0.043 & 0.098 & 0.118 & 0.315 & 0.225 & -0.089 & -0.456 & 1.000 \\
\hline Mean & 1.92 & 4.38 & 798.89 & 17846561.34 & 5.67 & 3132.24 & 31.34 & 26.56 \\
\hline Standard Deviation & 2.77 & 1.02 & 622.45 & 17889870.21 & 1.56 & 1863.34 & 32.39 & 5.56 \\
\hline Minimum & 0.01 & 0.89 & 165.56 & 560989.77 & 0.56 & 119.56 & 1.34 & 10.56 \\
\hline Maximum & 10.2 & 7.64 & 2812.52 & 83000000.00 & 7.45 & 9197.24 & 187.45 & 41.67 \\
\hline
\end{tabular}

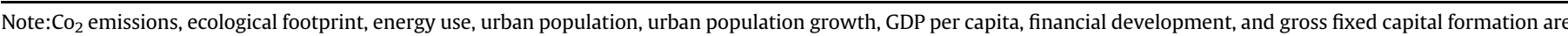

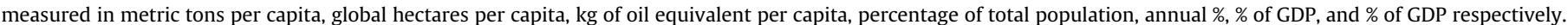
Source: Authors' Computations

Table 4

Variance inflation factor (VIF) results.

\begin{tabular}{|c|c|c|c|c|c|}
\hline \multicolumn{3}{|l|}{ Carbon Emissions } & \multicolumn{3}{|l|}{ Ecological Footprint } \\
\hline Variable & VIF & 1/VIF & Variable & VIF & $1 / \mathrm{VIF}$ \\
\hline GDP per capita, log & 2.47 & 0.404858 & Energy Use per capita, log & 1.37 & 0.729927 \\
\hline Energy Use per capita, log & 2.25 & 0.444444 & GDP per capita, log & 2.12 & 0.471698 \\
\hline Urban Population Growth & 1.44 & 0.694444 & Financial Development, log & 1.52 & 0.657894 \\
\hline Financial Development, log & 1.57 & 0.636942 & Urban Population, log & 2.03 & 0.492610 \\
\hline Gross Fixed Cap. Form., log & 1.26 & 0.793650 & Gross Fixed Cap. Form., log & 1.34 & 0.746268 \\
\hline Mean VIF & 1.79 & & Mean VIF & 1.67 & \\
\hline
\end{tabular}

Source: Authors' Computations

Table 5

Static and Dynamic Estimations on $\mathrm{CO}_{2}$ per capita, log.

\begin{tabular}{|c|c|c|c|c|}
\hline Variables & PCSE & PSCC & DPD & GMM \\
\hline Constant & $1.3217 * * *$ & $-0.1879 * * *$ & $\begin{array}{l}0.6512 \\
0.1862\end{array}$ & $\begin{array}{l}0.4352 \\
(1.45)\end{array}$ \\
\hline $\mathrm{CO}_{2}$ Emissions per capita_1, log & & & $(1.04)$ & $\begin{array}{l}0.0541 * * \\
(2.11)\end{array}$ \\
\hline Energy Use per capita, log & $\begin{array}{l}0.5307 * * * \\
(9.24)\end{array}$ & $\begin{array}{l}0.2768 * * * \\
(21.01)\end{array}$ & $\begin{array}{l}0.6971 * * * \\
(12.13)\end{array}$ & $\begin{array}{l}0.6023 * * * \\
(13.03)\end{array}$ \\
\hline Urban Population Growth & $\begin{array}{l}-0.0145^{* * * *} \\
(-6.12)\end{array}$ & $\begin{array}{l}-0.1812 * * * \\
(-10.43)\end{array}$ & $\begin{array}{l}-0.1445^{* *} \\
(-2.09)\end{array}$ & $\begin{array}{l}-0.0765^{* * *} \\
(-5.78)\end{array}$ \\
\hline GDP per capita, log & $\begin{array}{l}0.4518^{* * *} \\
(9.32)\end{array}$ & $\begin{array}{l}0.1265 * * * \\
(8.34)\end{array}$ & $\begin{array}{l}0.0455^{* * *} \\
(8.27)\end{array}$ & $\begin{array}{l}0.2461^{* * * *} \\
(8.21)\end{array}$ \\
\hline Financial Development, log & $\begin{array}{l}0.1276 * * * \\
(11.87)\end{array}$ & $\begin{array}{l}0.0945 * * * \\
(6.45)\end{array}$ & $\begin{array}{l}0.2871 * * * \\
(7.82)\end{array}$ & $\begin{array}{l}0.3298 * * * \\
(9.93)\end{array}$ \\
\hline Gross Fixed Cap. Formation, log & $\begin{array}{l}0.1111 \\
(0.96)\end{array}$ & $\begin{array}{l}-0.3462 \\
(-1.28)\end{array}$ & $\begin{array}{l}0.3425^{* *} \\
(2.17)\end{array}$ & $\begin{array}{l}0.2593 * * * \\
(3.33)\end{array}$ \\
\hline Groups & 44 & 44 & 44 & 44 \\
\hline Hansen Statistic & & & & 0.821 \\
\hline Sargan Statistic & & & 0.387 & \\
\hline AR (2) & & & & 0.85 \\
\hline $\begin{array}{l}\text { Mean VIF } \\
\text { R-Squared }\end{array}$ & 0.951 & 0.889 & & \\
\hline Wald/F Statistic & 1649.26 & 7954.60 & 42.54 & 1924.56 \\
\hline
\end{tabular}

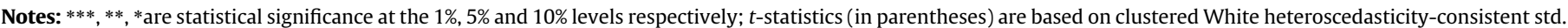
errors. VIF: Variance Inflation Factor.

Source: Authors' Computations

increase productive capacity, leading to the generation of harmful industrial pollutants contributing to environmental degradation. However, GFCF exhibits no meaningful effects on carbon emissions in both estimations.

In the event that the model suffers from endogeneity, dynamic estimations were performed. From the DPD analysis, energy use shows a significantly increase carbon emissions by $0.69 \%$. It indicates a positive relationship with a higher statistical significance of $1 \%$. Also, per capita GDP and financial development retain their positive clouts and statistical relevance at the $1 \%$ significant level. The arguments for per capita GDP and financial development are as previously elucidated. Agriculture contributes immensely to the 
GDP of Africa countries. Most Africa countries depend on mining and crop cultivation which develop through deforestation and could exacerbate the already increasing carbon emissions.

The system-GMM estimates also provide salient evidence on the persistence of environmental degradation in the model. It submits that the previous year's pollution level is a strong predictor of environmental degradation. That is, the previous level of degradation if not controlled has the tendency to further harm the environment by 0.05 per cent, on average, ceteris paribus. Similarly, energy use, GDP per capita, financial development, and gross fixed capital formation show significant positive relationship at the $1 \%$ level indicating that carbon emissions increase by $0.60,0.24,0.32$, and 0.25 per cent from a percentage change in energy use, GDP per capita, financial development, and gross fixed capital formation, on average, ceteris paribus. The reasoning is not far-fetched because firms with a more accumulated capital stock embark on an expansionary drive which involves more production activities with the usage of different energy-generating processes which may be harmful to the environment. Significant highlights from these analyses are that energy usage, per capita GDP and financial development contribute significantly to environmental degradation while urbanization declines carbon emissions. Again, these are important contributions to the literature. The mean VIF of 1.79 provides evidence of no multicollinearity in the model; the Hansen and Sargan statistics reveal that the model is well identified with good instruments.

\subsection{Static and dynamic analysis: ecological footprint model}

The findings reported in Table 6 are significantly different from those of Table 5 in signs and magnitudes of the coefficients. Though all the variables (except GFCF) show to be significant determinants of environmental degradation, energy use, per capita GDP, and financial development maintain their deteriorating impact across all model specifications. These outcomes are consistent with those of (Nathaniel 2020; Uddin et al., 2016; Nathaniel and Bekun, 2019; Omojolaibi and Nathaniel 2020; Ali et al., 2020; Sarkodie, 2018; Dogan et al., 2019; Meo et al., 2020; Nathaniel et al., 2020a,b,c,d).
These studies find that energy use is a strong determinant of environmental degradation. However, energy use showed a reduced deteriorating impact on the environment in comparison with the size of its coefficients in the $\mathrm{CO}_{2}$ emissions model. However, urbanization indicates a deteriorating impact when estimates from DPD and GMM analysis are considered. This is not in tandem with the results in the $\mathrm{CO}_{2}$ emissions model. GFCF shows to have mitigating effects on EFP across all model specifications. This suggests that capital formation in Africa is not yet at a desirable level where it can effectively enhance environmental sustainability.

\section{Conclusion and policy directions}

This study evaluates the determinants of carbon emissions within a panel of 44 African countries from 1992 to 2016 . The study engages a new approach by providing evidence on the consistency of the selected indicators in either inducing or alleviating environmental degradation. The findings reveal that energy use, urban population growth, per capita GDP, financial development and gross fixed capital formation are significant determinants of environmental degradation. The reasons for these outcomes are not farfetched and are likely to provoke more scientific investigations. However, there is evidence that the magnitude of the impact of each of the variables depends on the indicator of environmental degradation that is being considered. For instance, energy consumption showed a less deteriorating impact on the environment (when EF was used to capture environmental degradation) in comparison with the size of its coefficients in the $\mathrm{CO}_{2}$ emissions model. Based on the findings, the following policy suggestions are made:

$>$ Since results support that energy use is a positive contributor to $\mathrm{CO}_{2}$ emissions, the responsibility lies on African governments and the relevant stakeholders to harness the continent's richness of 'clean energy' sources like solar, geothermal, biomass, biogas, tidal power, photovoltaic and wind energy to avoid further deterioration of the environment. If this is not done in

Table 6

Static and Dynamic Estimations on EF per capita, log.

\begin{tabular}{|c|c|c|c|c|}
\hline Variables & PCSE & PSCC & DPD & GMM \\
\hline Constant & $\begin{array}{l}2.6785 \\
(-0.77)\end{array}$ & $\begin{array}{l}-1.6847 \\
(-0.06)\end{array}$ & $\begin{array}{l}0.4387 \\
(1.56)\end{array}$ & $\begin{array}{l}0.0054 \\
(1.65)\end{array}$ \\
\hline Ecol. Footprint per capita_1, log & & & $\begin{array}{l}0.5321 \\
(1.34)\end{array}$ & $\begin{array}{l}0.3827 * * \\
(2.21)\end{array}$ \\
\hline Energy Use per capita, log & $\begin{array}{l}0.0052 * * * \\
(7.23)\end{array}$ & $\begin{array}{l}0.0031 * * \\
(2.04)\end{array}$ & $\begin{array}{l}0.2543^{* * *} \\
(4.34)\end{array}$ & $\begin{array}{l}0.1221^{* * *} \\
(11.3)\end{array}$ \\
\hline Urban Population, log & $\begin{array}{l}0.7834 * * * \\
(15.07)\end{array}$ & $\begin{array}{l}0.2145^{* * *} \\
(5.34)\end{array}$ & $\begin{array}{l}0.3424 * * \\
(2.12)\end{array}$ & $\begin{array}{l}0.2323^{* * *} \\
(3.56)\end{array}$ \\
\hline GDP per capita, log & $\begin{array}{l}0.4563 * * * \\
(6.78)\end{array}$ & $\begin{array}{l}0.4199 * * * \\
(4.87)\end{array}$ & $\begin{array}{l}0.0456^{* * * *} \\
(5.02)\end{array}$ & $\begin{array}{l}0.2313^{* *} \\
(2.09)\end{array}$ \\
\hline Financial Development, log & $\begin{array}{l}0.5645^{* * * *} \\
(8.14)\end{array}$ & $\begin{array}{l}0.0675^{* * * *} \\
(16.01)\end{array}$ & $\begin{array}{l}0.2312 \\
(0.04)\end{array}$ & $\begin{array}{l}0.6661 \text { *** } \\
(9.23)\end{array}$ \\
\hline Gross Fixed Cap. Formation, log & $\begin{array}{l}-0.3110 \\
(-0.45)\end{array}$ & $\begin{array}{l}-0.0075 \\
(-1.32)\end{array}$ & $\begin{array}{l}-1.4536 \\
(-0.76)\end{array}$ & $\begin{array}{l}-0.3425 \\
(-0.26)\end{array}$ \\
\hline Groups/Instruments & 44 & 44 & 44 & 44 \\
\hline $\begin{array}{l}\text { Hansen Statistic } \\
\text { Sargan Statistic }\end{array}$ & & & 0.8234 & 0.235 \\
\hline $\begin{array}{l}\text { AR }(2) \\
\text { Mean VIF }\end{array}$ & & & & 0.4234 \\
\hline R-Squared & 0.957 & 0.878 & & \\
\hline Wald/F Statistic & 6876.50 & 587.675 & 20.56 & 29.879 \\
\hline
\end{tabular}

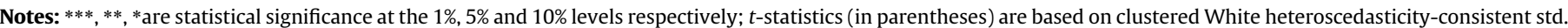
errors.

Source: Authors' Computations 
earnest, the possibility that biodiversity will remain grossly inhabitable abounds.

$>$ The study also proffers as a recommendation for the enforcement of strategies to achieve both the Paris Agreement and the Kyoto Protocol which is environmentally friendly given the awareness on climate change and its implications (consequences).

$>$ Africa government can overturn the adverse effects of energy consumption on the environment by gradually transiting to the consumption of renewables. This, of course, will not be an easy sail considering the low-income level in Africa. However, policymakers can start by providing the household with palliatives in the form of tax holiday, low-interest rate, and tax rebate. These will serve little more than succour and put the household in a better position to increase their consumption of renewables.

$>$ Now, since Africa is mainly a resource-dependent continent. The region's economy heavily depends on its natural resource endowments. However, most of these resources (petroleum, coal, natural gas etc.) and some activities like (mining, natural resource exploration, agriculture, etc.) encourages deforestation, biocapacity depletion, and increasing EF. Therefore, another possible way to enhance environmental sustainability and reducing the EF is to encourage sustainable practices in the natural resource sector and enhance the consumption of lesspolluting energy sources. By so doing, the resource will be allowed to regenerate, biocapacity will increase, while EF will decline.

$>$ Financial development is a significant contributor to environmental degradation in this study. The finding submits that financial intermediation has not been directed to environmental friendly sectors, hence stimulating pollution. To reverse the trend, financial resources need to be re-channelled such that more public awareness of environmental degradation is increased to the event that corporate organizations and industries can adopt new pollution moderating equipment and use cleaner energy in the production process. In addition, financial grants, subsidies and tax holidays will incentivize corporations to invest in cleaner technologies.

$>$ There are more global perspectives to this study, and it is super relevant to other researchers outside of Africa. Countries are expected to comply with the Paris Agreement of 2015 by reducing the consumption of non-renewables since these energy sources are pollutants. The mitigation of pollution could be achieved by consuming cleaner production technologies. Nevertheless, investing aggressively in the renewable energy sector will promote the development of cleaner production technologies.

Nevertheless, this study has implications for sustainability. The UN mandate for the implementation of the SDG-17 was endorsed on the first day of January 2016. Ever since, varying progress have been made by different countries to actualize the set goals. On the implications of the findings for sustainability, our findings exposed the need for Africa to braze-up and tackle the horrendous challenges created by climate change, SDG 13 (climate action). Energy use undeniably have a significant role in stimulating economic growth, expanding industrial capacity and ensuring societal wellbeing in Africa. Nonetheless, its influence in threatening environmental sustainability cannot be equally ignored. Thus, there is the need to engage the use of efficient energy-mix that will equally promote economic growth and ensure a cleaner and sustainable environment and thriving ecosystems. The adoption of renewable accompanied by cleaner production will, no doubt, help Africa in achieving SDG 7 (affordable and clean energy). The investment in renewable energy may slow down the growth process, but with time, the benefit associated with this energy source will create employment and make the environment ecologically sustainable. The growth trajectory, as a result of the consumption of renewables, will call for more investment in renewable energy thereby increasing its share in the continents energy mix.

This study was, however, limited by data availability. As such, not all African countries were considered. For instance, only fifty four African countries were sampled, which may not be a true reflection of the representation of the region. Also, this study did not accommodate all the determinants of $\mathrm{EF}$ and $\mathrm{CO}_{2}$ emissions. Future studies may want to consider the effects of governance and biomass production on $\mathrm{EF}$, and the various determinants of $\mathrm{CO}_{2}$ emissions, such as technical progress, innovation, human capital, and energy mix may be taken up.

\section{Authors contribution section}

Nathaniel Solomon conceptualized the idea. Worked on the introduction, reviewed the necessary literature, and provided the policy recommendation/direction for the study.

Adeleye Ngozi contributed in the analysis of the data.

\section{Declaration of competing interest}

The authors declare that they have no known competing financial interests or personal relationships that could have appeared to influence the work reported in this paper.

\section{Appendix}

\section{Lists of countries in the sample}

Gambia, Angola, South Africa, Gabon, Guinea-Bissau, Mauritius, Eritrea, Nigeria, Namibia, Algeria, Botswana, Tunisia, Zambia, Morocco, Liberia, Lesotho, Central African Rep., Egypt, Mauritania, Sudan, Congo, Libya, Cameroon, Kenya, Côte d'Ivoire, Rwanda, Sierra Leone, Ghana, Guinea, Senegal, Mozambique, Zimbabwe, Chad, Togo, Madagascar, Burundi, Malawi, Benin, Mali, Uganda, Burkina Faso, Somalia, Ethiopia, and Niger.

\section{References}

Abokyi, E., Appiah-Konadu, P., Abokyi, F., Oteng-Abayie, E.F., 2019. Industrial growth and emissions of $\mathrm{CO} 2$ in Ghana: the role of financial development and fossil fuel consumption. Energy Rep. 5, 1339-1353.

Acheampong, A.O., 2018. Economic growth, CO2 emissions and energy consumption: what causes what and where? Energy Econ. 74, 677-692.

Ahmed, Z. Wang, Z., 2019. Investigating the impact of human capital on the ecological footprint in India: an empirical analysis. Environ. Sci. Pollut. Control Ser. 26 (26), 26782-26796.

Ali, H.S., Nathaniel, S.P., Uzuner, G., Bekun, F.V., Sarkodie, S.A., 2020. Trivariate modelling of the nexus between electricity consumption, urbanization and economic growth in Nigeria: fresh insights from Maki Cointegration and causality tests. Heliyon 6 (2), e03400.

Aliyu, A.K., Modu, B., Tan, C.W., 2018. A review of renewable energy development in Africa: a focus in South Africa, Egypt and Nigeria. Renew. Sustain. Energy Rev. 81, 2502-2518.

Altıntaş, H., Kassouri, Y., 2020. Is the environmental Kuznets Curve in Europe related to the per-capita ecological footprint or $\mathrm{CO} 2$ emissions? Ecol. Indicat. 113, 106187.

Ansari, M.A., Haider, S., Khan, N.A., 2020. Environmental Kuznets curve revisited: an analysis using ecological and material footprint. Ecol. Indicat. 115, 106416.

Arellano, M., Bond, S., 1991. Some tests of specification for panel data: Monte Carlo evidence and an application to employment. Rev. Econ. Stud. 58, 277-297.

Arellano, M., Bover, O., 1995. Another look at the instrumental variable estimation of error-components models. J. Econom. 68 (1), 29-51.

Asongu, S., El Montasser, G., Toumi, H., 2016. Testing the relationships between energy consumption, CO 2 emissions, and economic growth in 24 African countries: a panel ARDL approach. Environ. Sci. Pollut. Control Ser. 23 (7), 6563-6573.

Aydin, C., Esen, Ö., Aydin, R., 2019. Is the ecological footprint related to the Kuznets curve a real process or rationalizing the ecological consequences of the 
affluence? Evidence from PSTR approach. Ecol. Indicat. 98, 543-555.

Aziz, N., Sharif, A., Raza, A., Rong, K., 2020. Revisiting the role of forestry, agriculture, and renewable energy in testing environment Kuznets curve in Pakistan: evidence from Quantile ARDL approach. Environ. Sci. Pollut. Control Ser. 1-14.

Baz, K., Xu, D., Ali, H., Ali, I., Khan, I., Khan, M.M., Cheng, J., 2020. Asymmetric impact of energy consumption and economic growth on ecological footprint: using asymmetric and nonlinear approach. Sci. Total Environ. 718, 137364.

Chang, C.P., Dong, M., Sui, B., Chu, Y., 2019. Driving forces of global carbon emissions: from time-and spatial-dynamic perspectives. Econ. Modell.

Churchill, S.A., Inekwe, J., Smyth, R., Zhang, X., 2019. R\&D intensity and carbon emissions in the G7: 1870-2014. Energy Econ. 80, 30-37.

da Silva, P.P., Cerqueira, P.A., Ogbe, W., 2018. Determinants of renewable energy growth in Sub-Saharan Africa: evidence from panel ARDL. Energy 156, 45-54.

Danish, Wang, Z., 2019. Investigation of the ecological footprint's driving factors: what we learn from the experience of emerging economies. Sustainable Cities and Society 49.

Destek, M.A., Sinha, A., 2020. Renewable, non-renewable energy consumption, economic growth, trade openness and ecological footprint: evidence from organisation for economic Co-operation and development countries. J. Clean. Prod. 242, 118537.

Dinda, S., 2004. Environmental Kuznets curve hypothesis: a survey. Ecol. Econ. 49 (4), 431-455.

Dogan, E., Taspinar, N., Gokmenoglu, K.K., 2019. Determinants of ecological footprint in MINT countries. Energy Environ. 0958305X19834279.

Dogan, E., Ulucak, R., Kocak, E., Isik, C., 2020. The use of ecological footprint in estimating the Environmental Kuznets Curve hypothesis for BRICST by considering cross-section dependence and heterogeneity. Sci. Total Environ. 138063.

Driscoll, J.C., Kraay, A.C., 1998. Consistent covariance matrix estimation with spatially dependent panel data. Rev. Econ. Stat. 80, 549-560.

EIA, U., 2013. Annual Energy Outlook 2013. US Energy Information Administration, Washington, DC, pp. 60-62.

Fakher, H.A., 2019. Investigating the determinant factors of environmental quality (based on ecological carbon footprint index). Environ. Sci. Pollut. Control Ser. 26 (10), 10276-10291.

Ghazali, A., Ali, G., 2019. Investigation of key contributors of $\mathrm{CO} 2$ emissions in extended STIRPAT model for newly industrialized countries: a dynamic common correlated estimator (DCCE) approach. Energy Rep. 5, 242-252.

Halicioglu, F., Ketenci, N., 2016. The impact of international trade on environmental quality: the case of transition countries. Energy 109, 1130-1138.

Hansen, J., Satoa, M., Ruedy, R., Schmidtc, G.A., Lob, K., Persinb, A., 2017. Global Temperature in 2016.

He, F.S., Gan, G.G.G., Al-Mulali, U., Solarin, S.A., 2019. The influences of economic indicators on environmental pollution in Malaysia. Int. J. Energy Econ. Pol. 9 (2), 123-131.

Jayanthakumaran, K., Liu, Y., 2012. Openness and the environmental Kuznets curve: evidence from China. Econ. Modell. 29 (3), 566-576.

Khan, A.Q., Saleem, N., Fatima, S.T., 2018. Financial development, income inequality, and CO 2 emissions in Asian countries using STIRPAT model. Environ. Sci. Pollut. Control Ser. 25 (7), 6308-6319.

Khan, A., Chenggang, Y., Xue Yi, W., Hussain, J., Sicen, L., Bano, S., 2020. Examining the pollution haven, and environmental kuznets hypothesis for ecological footprints: an econometric analysis of China, India, and Pakistan. J. Asia Pac. Econ. 1-21.

Khan, S.A.R., Qianli, D., 2017b. Impact of green supply chain management practices on firms' performance: an empirical study from the perspective of Pakistan. Environ. Sci. Pollut. Control Ser. 24 (20), 16829-16844.

Khan, S.A.R., Jian, C., Zhang, Y., Golpîra, H., Kumar, A., Sharif, A., 2019b. Environmental, social and economic growth indicators spur logistics performance: from the perspective of South Asian Association for Regional Cooperation countries. J. Clean. Prod. 214, 1011-1023.

Khan, S.A.R., Zaman, K., Zhang, Y., 2016. The relationship between energy-resource depletion, climate change, health resources and the environmental Kuznets curve: evidence from the panel of selected developed countries. Renew. Sustain. Energy Rev. 62, 468-477.

Li, S., Zhou, C., Wang, S., 2019. Does modernization affect carbon dioxide emissions? A panel data analysis. Sci. Total Environ. 663, 426-435.

Lin, B., Raza, M.Y., 2019. Analysis of energy related CO2 emissions in Pakistan. J. Clean. Prod.

Liu, D., Xiao, B., 2018. Can China achieve its carbon emissions peaking? A scenario analysis based on STIRPAT and system dynamics model. Ecol. Indicat. 93, 647-657.

Liu, Y., Hao, Y., 2018. The dynamic links between CO2 emissions, energy consumption and economic development in the countries along "the Belt and Road". Sci. Total Environ. 645, 674-683.

Ma, X., Wang, C., Dong, B., Gu, G., Chen, R., Li, Y., et al., 2019. Carbon emissions from energy consumption in China: its measurement and driving factors. Sci. Total Environ. 648, 1411-1420.

Mahalik, M.K., Mallick, H., Padhan, H., Sahoo, B., 2018. Is skewed income distribution good for environmental quality? A comparative analysis among selected BRICS countries. Environ. Sci. Pollut. Control Ser. 25 (23), 23170-23194.

Mardani, A., Streimikiene, D., Cavallaro, F., Loganathan, N., Khoshnoudi, M., 2019. Carbon dioxide (CO2) emissions and economic growth: a systematic review of two decades of research from 1995 to 2017. Sci. Total Environ. 649, 31-49.

Meo, M.S., Nathaniel, S.P., Khan, M.M., Nisar, Q.A., Fatima, T., 2020. Does temperature contribute to environment degradation? Pakistani experience based on nonlinear bounds testing approach. Global Bus. Rev. 0972150920916653.

Mikayilov, J.I., Mukhtarov, S., Mammadov, J., Azizov, M., 2019. Re-evaluating the environmental impacts of tourism: does EKC exist? Environ. Sci. Pollut. Control Ser. $1-14$.

Nathaniel, S.P., 2019. Modelling urbanization, trade flow, economic growth and energy consumption with regards to the environment in Nigeria. Geojournal $1-15$

Nathaniel, S.P., 2020. Ecological footprint, energy use, trade, and urbanization linkage in Indonesia. Geojournal 1-14.

Nathaniel, S.P., Bekun, F.V., 2019. Environmental management amidst energy use, urbanization, trade openness, and deforestation: the Nigerian experience. J. Publ. Aff.

Nathaniel, S.P., Iheonu, C.I., 2019. Carbon dioxide abatement in Africa: the role of renewable and non-renewable energy consumption. Sci. Total Environ. 679, 337-345.

Nathaniel, S.P., Nwulu, N., Bekun, F., 2020d. Natural resource, globalization, urbanization, human capital, and environmental degradation in Latin American and Caribbean countries. Environ. Sci. Pollut. Control Ser. 1-15.

Nathaniel, S., Aguegboh, E., Iheonu, C., Sharma, G., Shah, M., 2020b. Energy consumption, FDI, and urbanization linkage in coastal Mediterranean countries: reassessing the pollution haven hypothesis. Environ. Sci. Pollut. Control Ser. 27 (28), 35474-35487.

Nathaniel, S., Anyanwu, O., Shah, M., 2020a. Renewable energy, urbanization, and ecological footprint in the Middle East and North Africa region. Environ. Sci. Pollut. Control Ser. 1-13.

Nathaniel, S., Nwodo, O., Adediran, A., Sharma, G., Shah, M., Adeleye, N., 2019. Ecological footprint, urbanization, and energy consumption in South Africa: including the excluded. Environ. Sci. Pollut. Control Ser. 1-12.

Nathaniel, S., Nwodo, O., Sharma, G., Shah, M., 2020c. Renewable energy, urbanization, and ecological footprint linkage in CIVETS. Environ. Sci. Pollut. Control Ser. 27 (16), 19616-19629.

Nguyen, K.H., Kakinaka, M., 2019. Renewable energy consumption, carbon emissions, and development stages: some evidence from panel cointegration analysis. Renew. Energy 132, 1049-1057.

Omojolaibi, J., Nathaniel, S.P., 2020. Assessing the potency of environmental regulation in maintaining environmental sustainability in MENA countries: an advanced panel data estimation. J. Publ. Aff., e2526

Rudolph, A., Figge, L., 2017. Determinants of Ecological Footprints: what is the role of globalization? Ecol. Indicat. 81, 348-361.

Sabir, S., Gorus, M.S., 2019. The impact of globalization on ecological footprint: empirical evidence from the South Asian countries. Environ. Sci. Pollut. Control Ser. $1-12$.

Salahuddin, M., Alam, K., Ozturk, I., Sohag, K., 2018. The effects of electricity consumption, economic growth, financial development and foreign direct investment on CO2 emissions in Kuwait. Renew. Sustain. Energy Rev. 81, 2002-2010.

Sarkodie, S.A., 2018. The invisible hand and EKC hypothesis: what are the drivers of environmental degradation and pollution in Africa? Environ. Sci. Pollut. Control Ser. 25 (22), 21993-22022.

Sarkodie, S.A., Ozturk, I., 2020. Investigating the environmental kuznets curve hypothesis in Kenya: a multivariate analysis. Renew. Sustain. Energy Rev. 117 109481.

Sarkodie, S.A., Strezov, V., 2019. Effect of foreign direct investments, economic development and energy consumption on greenhouse gas emissions in developing countries. Sci. Total Environ. 646, 862-871.

Sarkodie, S.A., Strezov, V., Weldekidan, H., Asamoah, E.F., Owusu, P.A., Doyi, I.N.Y., 2019. Environmental sustainability assessment using dynamic AutoregressiveDistributed Lag simulations-nexus between greenhouse gas emissions, biomass energy, food and economic growth. Sci. Total Environ.

Shabani, Z.D., Shahnazi, R., 2019. Energy consumption, carbon dioxide emissions, information and communications technology, and gross domestic product in Iranian economic sectors: a panel causality analysis. Energy 169, 1064-1078.

Shahbaz, M., Sinha, A., 2019. Environmental Kuznets curve for CO2 emissions: a literature survey. J. Econ. Stud. 46 (1), 106-168.

Shahbaz, M., Balsalobre-Lorente, D., Sinha, A., 2019. Foreign direct Investment-CO2 emissions nexus in Middle East and North African countries: importance of biomass energy consumption. J. Clean. Prod. 217, 603-614.

Shahbaz, M., Shahzad, S.J.H., Mahalik, M.K., 2018. Is globalization detrimental to CO 2 emissions in Japan? New threshold analysis. Environ. Model. Assess. 23 (5), 557-568.

Sharif, A., Baris-Tuzemen, O., Uzuner, G., Ozturk, I., Sinha, A., 2020. Revisiting the role of renewable and non-renewable energy consumption on Turkey's ecological footprint: evidence from Quantile ARDL approach. Sustainable Cities and Society 102138.

Sharma, R., Sinha, A., Kautish, P., 2020. Examining the impacts of economic and demographic aspects on the ecological footprint in South and Southeast Asian countries. Environ. Sci. Pollut. Control Ser. 1-13.

Sinha, A., Gupta, M., Shahbaz, M., Sengupta, T., 2019. Impact of corruption in public sector on environmental quality: implications for sustainability in BRICS and next 11 countries. J. Clean. Prod.

Uddin, G.A., Alam, K., Gow, J., 2016. Does ecological footprint impede economic growth? An empirical analysis based on the environmental Kuznets curve hypothesis. Aust. Econ. Pap. 55 (3), 301-316.

Ulucak, R., Khan, S.U.D., 2020. Determinants of the ecological footprint: role of 
renewable energy, natural resources, and urbanization. Sustainable Cities and Society 54, 101996.

UN-Habitat, 2016. World cities report 2016: urbanization and development emerging futures. Retrieved from. https://unhabitat.org/books/world-citiesreport/.

United Nation, 2018. The sustainable development Goals report 2018. Available at: https://unstats.un.org/sdgs/files/report/2018/

TheSustainableDevelopmentGoalsReport2018-EN.pdf.

Wang, J., Dong, K., 2019. What drives environmental degradation? Evidence from 14 Sub-Saharan African countries. Sci. Total Environ. 656, 165-173.

Wang, S., Wang, J., Li, S., Fang, C., Feng, K., 2019. Socioeconomic driving forces and scenario simulation of $\mathrm{CO} 2$ emissions for a fast-developing region in China. J. Clean. Prod.
Winoto, J., Schultink, G., 1996. Impacts of Urbanization on Agricultural Sustainability and Rural Life in West Java, Indonesia (April). Michigan Agricultural Experiment Station Michigan State University. Retrieved from.

Zafar, M.W., Zaidi, S.A.H., Khan, N.R., Mirza, F.M., Hou, F., Kirmani, S.A.A., 2019. The impact of natural resources, human capital, and foreign direct investment on the ecological footprint: the case of the United States. Resour. Pol. 63, 101428.

Zhang, Y., Khan, S.A.R., Kumar, A., Golpîra, H., Sharif, A., 2019. Is tourism really affected by logistical operations and environmental degradation? An empirical study from the perspective of Thailand. J. Clean. Prod. 227, 158-166.

Zhou, Y., Fu, J., Kong, Y., Wu, R., 2018. How foreign direct investment influences carbon emissions, based on the empirical analysis of Chinese urban data. Sustainability 10 (7), 2163. 